\title{
CrimRxiv
}

\section{The Meaning of the Victim- Offender Overlap for Criminological Theory and Crime Prevention Policy}

Mark Berg' ${ }^{1}$, Christopher Schreck ${ }^{2}$

${ }^{1}$ University of lowa, ${ }^{2}$ Rochester Institute of Technology

Published on: May 26, 2021

DOI: $10.21428 / \mathrm{cb} 6 \mathrm{ab} 371.322 \mathrm{ebfb5}$

License: Creative Commons Attribution 4.0 International License (CC-BY 4.0). 


\section{ABSTRACT}

Criminological theory developed without an expectation of a victim-offender overlap. Among most crime theorists and policymakers, to solve crime it is necessary to solve the criminal offender. Modern choice theories took a different view by evolving from victim data, treating target vulnerability as essential to the criminal act and with full awareness of the overlap. Here, we discuss the emphasis on offenders in criminology as being inconsistent with the facts of the overlap. The evidence shows that the victimoffender overlap is consistently found, implying that offending and victimization arise for similar substantive reasons and that offenders act principally in response to targets. This conclusion has important implications. First, any theory of crime that cannot logically predict the overlap as a fact may be subject to falsification. Second, the choice perspective suggests a theory of precautionary behavior, which urges a policy agenda that encourages actions against crime by potential targets.

\section{INTRODUCTION}

Criminology's prominent theories often feature variables that can boast modest success at predicting criminal behavior. As correlates go, the same cannot be said for self-reported victimization, which is an experience that is quite strongly linked with offending. Indeed, not long after the advent of the first large-scale victim surveys in the 1970s, Reiss (1981, p. 711) concluded that "any theory that assumes no overlap exists between populations of victims and offenders or that they are distinct types of persons distorts the empirical research." By and large, four decades of subsequent research have yet to prove Reiss wrong (Berg\& Mulford 2020, Lauritsen \& Laub 2007). The correlation, besides being strong, appears to persist across diverse groups, time periods, and locations, all of which arguably situate it among the most important basic facts of crime. Yet criminologists have not granted sufficient attention to the implications of the overlap for the explanation and control of crime. Facts do not have automatic meaning.

Criminology's response was to proceed as if the victim-offender overlap was unnecessary for understanding crime and its prevention. Instead, the criminal offender is and remains the mainstay of criminology and favored with overwhelming attention. Not surprisingly, policy recommendations to practitioners reflect this prioritization. A 2020 report on the science of violence reduction strategies is but a recent example: The offender's circumstance is the common denominator across nearly all the policy proposals-e.g., limiting access to guns, controlling substance abuse, changing 
antisocial norms (John Jay_ Coll. Res. Advis. Group Prev. Reducing_Community_ Violence 2020). To what degree any of these policies are relevant to the crime target is indirect. Criminological explanations of the crime drop beginning in the early 1990s similarly center on the offender (

Situational perspectives of choice and opportunity, by contrast, weigh the actions of the crime victim, but they, too, have shown limited interest in explaining these actions: rather, the substantive goal is to understand how to manipulate the offender's cost perceptions to thwart crime events ( (e.g., Farrell et al. 2011), the prevailing message in criminology is apparent: solve the offender, and one solves the crime problem.

Within certain segments of criminology, however, the victim-offender overlap was profoundly influential. A handful of major crime theories were built upon findings from victim data, and these acknowledged the overlap as well as the importance of target behavior in the etiology of the criminal act (Berg \& Felson 2016, Gottfredson 2021). If the target's actions mattered to the offender's decisions, the natural next step would be for theorists to explore the reasons for the behaviors of crime targets. And the victim-offender overlap offered some important insights. By the late 1990s, it was becoming clear that offenders and victims shared many qualities. These included a preference for activities that allowed the actor the freedom to perpetrate not only criminal acts but also activities that heightened their vulnerability to victimization (Osgood et al. 1996, Schreck 1999, Schreck \& Berg_2021, Turanovic \& Pratt 2019). This meant that similar processes accounted for both offending and victimization-a possibility that suggests a basic policy agenda for criminology focused on the modification of target behavior. If easy and inexpensive precautionary actions effectively remove opportunity from would-be offenders, it would seem to follow that fostering their widespread and consistent use ought to be a policy priority. Whatever approach is effective at solving the offender ought to reduce the vulnerability of individuals to crime as well. The usual policy alternatives, however, are directed solely toward the offender, and these efforts often involve the force of the criminal justice system.

Whereas the victim-offender overlap is a basic fact supported by ample science, a fact urging attention to crime target decision-making, the offender focus is a puzzling feature of modern criminology. Thus, it seems that a demonstration of how a single process underlies both offending and vulnerability to crime is valuable to both criminological theory and prevention policy. With this objective in mind, we review the 
general contours of the empirical evidence on the overlap, showing its robustness (see also Berg_2012 Lauritsen \& Laub 2007). Note that we except from this review acts of child abuse, elder abuse, victimization of those who are in legal custody, or any related crimes where the victim is not able to exercise choice or where it is not realistic to make choice an option. We describe how theories of crime have attempted to address the overlap, although we do not assert that all theories can produce hypotheses consistent with the evidence (Schreck \& Berg 2021). For those theories that can do so, however, the victim-offender overlap may provide guidance about the treatment of the other side of the crime equation: the decision-making of the human target. We conclude by developing the implications of the victim-offender overlap for advancing our understanding of crime causation as well as for informing the general principles of crime prevention policy.

\section{THE NATURE AND EXTENT OF THE VICTIM-OFFENDER OVERLAP}

Criminology historically took no firm position on the relationship between victimization and offending, probably because it was not anticipated by the foundational presuppositions of the discipline. With the emergence and popularity of positivism, criminals were assumed to be differentiated from others in the population, their behavior arising from specific and observable pathologies that caused them to break the law (Roshier 1989). Statements from crime scholars during the mid-twentieth century appeared logically consistent with this stance and often reflected a belief that offenders and victims were separate entities (e.g., Sykes \& Matza 1957, von Hentig. 1948). Scarcely mentioned in that work is the would-be victim as an active agent making choices that affect criminal opportunity-instead, in these theories, criminals made their own opportunities (Gottfredson \& Hirschi 2003).

The discovery of the victim-offender overlap in the mid-twentieth century was a result of statistical analyses of official crime data. Some of the earliest evidence was reported in Wolfgang's (1958). study of homicide incidents in Philadelphia. He determined that most murder victims had arrest records, often for violent crimes, and many of the victims engaged in behaviors that precipitated the homicide events. These findings initially provoked little theoretical reaction, and Wolfgang and his contemporaries supposed the overlap to be a cultural artifact confined to areas of urban poverty (Singer 1986). Nevertheless, Thornberry \& Figlio (1974), using data from a birth cohort, examined victimization and offending across demographic groups and found patterns of persistence (see also Singer 1981). But as is often the case with many 
research findings that are arrived at inductively, there was little reason for criminology to elevate the matter to a research priority and revise its theories accordingly.

The emergence of large-scale surveys in the United States and abroad during the 1970s wrought a gradual change, producing a literature showing that victims and offenders had remarkably equivalent sociodemographic profiles (Hindelang_

$\underline{1976}, \underline{1981}$ ). This work also revealed that the victim-offender overlap was not at all confined to specific social conditions (e.g., Sparks \& Dodd 1977). In fact, it seems to be found practically everywhere. Gottfredson's (1984). analysis of the British Crime Survey revealed the victim-offender overlap was not exclusive to the United States, high-risk groups, or acts of serious criminal offending among urbanites but present in the general population. Subsequent studies in other countries would report similar findings (e.g., Enzmann et al. 2017). Noteworthy is the fact that Gottfredson also found a correlation between victimization and self-reported traffic accidents, which spoke to the existence of shared substantive correlates between risky behavior and victimization beyond the demographic similarities discovered to that point (Hindelang. 1981). Lauritsen and her colleagues (1992), using data from the National Youth Survey, went further and examined substantive variables that were purported to be causes of crime-e.g., elements of the social bond and deviant peer associations-and found that these variables also predicted victimization. This work also found that, relative to variables implied in major criminological theories, self-reported delinquent and criminal behavior had some of the strongest effects on an individual's risk of violent victimization (Lauritsen et al. 1992), a pattern also evident in prospective longitudinal studies of youth (e.g., Loeber et al. 2001).

With such findings, it was becoming clear that criminological theories offered a readymade starting point for understanding the choices and individual differences that produced vulnerability to crime. More recent work only continues this pattern of findings, but in other scientific domains the determinants of crime and victimization also predict injury, accidents, and poor health (see Junger et al. 1995, Moffitt et al. 2011, Odgers et al. 2007, Skinner et al. 2020). Moreover, analyses of fatal and nonfatal shootings have shown that both victims and offenders are clustered in homogamous social networks (e.g., Papachristos et al. 2015). The idea of shared correlates would prove crucial for criminology, as it questioned the practice of treating theories of criminality and victimization as unrelated topics (Schreck $\boldsymbol{\&}$ Berg 2021$)$.

Naturally enough, because there are innocent victims of crime, researchers attempted to test the limits of the overlap by ascertaining whether offending and victimization 
had distinctive etiologies-or, at least, correlates that predicted one outcome more so than the other. Schreck and colleagues (2008). illustrate one of these attempts using nationally representative data from a sample of adolescents from the United States. Although there were clearly "pure types" of offenders and victims, as expected, the data showed that the broader pattern was that of an overlap between the roles (see also Melde et al. 2016). Situational research from Switzerland provided evidence that masculinity norms predicted a greater tendency to be an offender than a victim, whereas anxiety and depression predicted a greater tendency to be a victim (Van Gelder et al. 2015), suggesting that role differentiation is an empirical reality, although its prevalence is not clear. The more usual patterns for variables producing differentiation into victim and offender roles, however, tend not to be theoretically anticipated; neither do there seem to be consistent patterns in the results across later studies (e.g., Reid \& Sullivan 2012).

In short, victims and offenders share the same substantive predictors (see also Lauritsen \& Laub 2007), and this is true in samples throughout the world. The evidence indicates that there are very few consistently trustworthy correlates that distinguish them, suggesting that what has been found so far are artifacts of the data. Or, put another way, criminology has yet to make a plausible empirical case for treating offenders and victims as separate entities created by unique processes, beyond victims who cannot offend because they lack the physical capacity to do so (e.g., the frailest of elderly, small children, the disabled).

In addition to work attempting to differentiate victims from offenders, there have been efforts to explore the changing nature of the victim-offender overlap across the life course (e.g., Beckley et al. 2018, Reisig\& Holtfreter 2018). Some researchers have speculated that victimization might initiate a desistance process in criminal offending, which is to say that the direction of the victim-offender correlation either vanishes or turns from positive to negative (see Lauritsen \& Laub 2007). Farrall \& Calverley_(2006), for instance, noticed that the arrest of adult probationers seemed to be unaffected by experiences with victimization. Ethnographic work reports that former offenders attribute their own cessation from criminal activity to victimization and the dangers it posed to valued parts of their lives (e.g., Carlsson 2013). The strength of the within-person relationship between offending and victimization does decline as individuals age, apparently because of maturational reform rather than the influence of substantive variables anticipated in the life-course framework (Schreck et al. 2017). The empirical literature thus offers little evidence that, over time, victimization is a cause of desistance from crime. 
The victim-offender overlap also appears to persist across relational settings and units of analysis. In the context of intimate partner violence especially, offenders and their targets are assumed to be clearly distinct groups. Yet victimization and offending are strongly correlated among those most likely to attack their partners (Moffitt et al. 2001, Taylor et al. 2019, Tillyer \& Wright 2014). The overlap is evident even in controlled settings, such as among prisoners (Daquin \& Daigle 2020) and in surveys of peer aggression in preschools (Barker et al. 2008). Researchers have continued to assess the presence of the overlap among demographic groups, such as Native Americans (Reingle \& Maldonado-Molina 2012). Just as there seem to be few settings where the overlap is not present, it is reasonable to conclude that there is no demographic group where an overlap does not exist. It varies in strength; in fact, multilevel research suggests that the strength of the relationship between offending and victimization varies across neighborhood contexts, indicating the relationship is stronger in disadvantaged neighborhoods and weaker in low poverty environments (Berg\& Loeber 2011).

Although the findings from research on the victim-offender overlap are rather consistent, there remain methodological challenges (see Berg\& Mulford 2020). One of these is the issue of whether offending precedes victimization or the reverse (Ousey et al. 2011). Some scholars have suggested that knowing whether victimization preceded offending could cast crucial light on whether, for instance, much of the overlap involves retaliation or whether victimization is part of the life-course pathway of criminal offending (see Lauritsen \& Laub 2007). Attempts to resolve this issue typically involve the specification of lag periods between measures of victimization and offending. The researcher thus imposes causal ordering on the overlap. However, these lags probably omit information about activities that occur between waves. Whether lagged specifications add substantial clarity to the inferences from causal estimates of the overlap is debatable (Wilcox et al. 2009). Further complicating matters is the fact that the same person can occupy the role of victim and offender in a single crime incident (Berg_ 2012). Linking self-reports of offending to incidents of selfreported victimization therefore means that researchers probably derive estimates of the correlation between crime events and not necessarily acts. As Berg\& Mulford (2020, p. 26) argue, "placing victimization and offending in its proper temporal sequence within an incident is generally not feasible given the imprecision of available self-report measurement instruments and study protocols." So, in this way, the specification of lags may not alter the known facts of the overlap. 
Another challenge of methodological and substantive importance relates to that of selection bias. Preexisting differences potentially sort individuals into violent events and thereby confound the correlation between offending and victimization. Without proper adjustments for selection bias, whether unobserved or observed or time-stable or time-varying, research might overstate the strength of the overlap. Estimates from longitudinal studies with adjustments for selection have found that the positive correlation between offending and victimization remains significant and robust (Berg_ \& Loeber 2011, Chen 2009, Ousey et al. 2011). However, selection bias should be conceived as less of a methodological problem than a theoretical puzzle. In other words, the processes underlying selection have theoretical meaning, and any assertions about the explanatory role of selection bias should be connected to a theoretical framework that articulates the qualities of that bias. To assert that selection effects might account for some portion of the victim-offender overlap does not provide the researcher with the substantive information necessary for developing theory and policy.

Methodological challenges notwithstanding, what we can be sure of is that victimization is nearly everywhere positively correlated with criminal behavior. Any variance in the strength of the victim-offender overlap is inconsequential insofar as it remains as stable a fact as any other that is accepted by criminologists as foundational to the understanding of crime (e.g., age-crime curve). Whereas criminologists a halfcentury ago understandably did not need to be responsive to the implications of the victim-offender overlap for theory and policy, the situation has changed markedly.

\section{EXPLANATIONS FOR THE VICTIM-OFFENDER OVERLAP}

The presence of a victim-offender overlap, however stable and ubiquitous, does not automatically reveal the ways in which it is important. Few major crime theorists offered direct and explicit explanations (Schreck et al. 2008). Victimization researchers, however, quickly grasped the implications of what the data showed (e.g., Gottfredson 1984, Reiss 1981). In one of the first studies of large-scale victimization data, Hindelang_(1976). was impressed enough with the similarity of offenders and victims to propose that crime theory be expanded to account for victimization. Yet until the early 1990s, there was little sign that theorists saw value in developing the theoretical or policy implications of the victim-offender overlap. Here, we review what some major theories have reported to date. 


\section{Cultural Explanations}

For almost a century, culture has held a preeminent place among the purported causes of crime, especially acts of interpersonal violence. These theories hypothesize linkages between the presence of a subculture or oppositional culture in the social environment and variation in rates of crime and violence. According to these frameworks, members of one group learned from their social environment prescriptive conduct norms that called for behavior that other groups defined in their legal codes as non-normative and criminal. Human action thus arises out of scripts or definitions concerning right and wrong. Cultural theories have long taken the view that the victim-offender overlap is a product of conduct norms that endorse crime and violence (see Lauritsen \& Laub 2007).

Consistent with these assumptions, Wolfgang_(1958). explained the similarity of victims and offenders by implicating norms of honor among the lower classes. Singer (1986) elaborated this theory further. Here, the overlap was a product of a cultural environment in which vengeance was a constituent part. According to $\underline{\text { Singer }} \mathbf{\text { (1986 }}$, p. 61), in places where people hold attitudes favoring violence, their conflicts often evolve into "reciprocal exchange[s] in which violence is followed by retaliation." Victims of crime may become offenders because of norms that justify retaliation. In this way, the experience of victimization prompts a script calling for reprisal. This is in clear contrast to the scripted response of the middle class, where "dominant cultural values dictate calling the police" (Singer 1986, p. 68). Or, put differently, an overlap exists only in certain elements of the lower class where retaliation is a normative feature but not elsewhere and especially not among the middle classes, where individuals are socialized to employ alternative means of conflict resolution such as calling the police.

Cultural accounts typically describe a value system centering on a concept of personal honor involving the maintenance of respect. Here, respect is a valued status that is easily lost, which produces a low tolerance for insults. Violations of self by others symbolize hostile intent, irrespective of actual intent. The appropriate response for managing these transgressions is to "immediately enforce [their] precedence" through physically attacking the offending party (Horowitz 1983, p. 82). Under these circumstances, victimization takes on a broad meaning, justifying a retaliatory strike

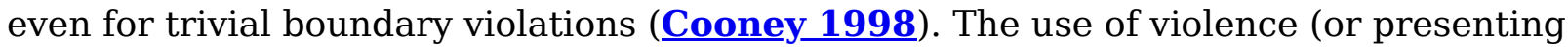
a willingness to use violence) enhances status; however, a failure to do so jeopardizes status. In this way, those who present less aggressively, or who are conciliatory, appear 
weak. Thus, as in Singer's (1986). model, Anderson's (1999). account of the street code in modern urban settings suggests special conditions in which the victimoffender overlap does not apply. Those who are less invested in the idea that their standing depends on a willingness to be violent, and who present as insufficiently belligerent, will be treated as "chumps" and victimized (Stewart et al. 2006). As Anderson (1999, p. 130) argued, it is imperative "not to allow others to chump you" and therefore the "message that you are not a pushover must be sent loudly and clearly." A basic interpretation of cultural accounts suggests that where the honor code is prominent, individuals become involved as offenders and victims and become entangled in antisocial acts more generally. The overlap among victims and offenders, and the rotation of individuals across these two roles, is thus a product of this cultural arrangement favoring violence and predation. Qualitative studies provide rich illustrations of how acts of violent retaliation unfold in the streets as a result of perceived violations of honor and respect (Jacobs \& Wright 2006).

Early multivariate research on the role of conduct norms in shaping the victimoffender overlap did not specify measures of these cultural processes. This research, instead, usually concluded that subcultural processes were a causal explanation based on mere evidence of a correlation between offending and victimization (e.g., $\underline{\text { Singer }}$ 1981). Studies have since specified measures consistent with different conceptualizations of cultural processes to test the predictions of this perspective. This body of work has found that adherence to honor-related codes increases offending and victimization risk (Felson et al. 2018, Melde et al. 2016), providing further evidence of shared correlates. Furthermore, research has found that the presence of these codes in the neighborhood context increases the strength of the victim-offender overlap (Berget al. 2012). However, these effects are not exclusive to the urban areas described by Wolfgang_(1958); rather, honor norms are present in a variety of social environments to varying degrees and correspond to greater risk of victimization and offending ( $\underline{\mathbf{O} \text { 2020}}$ ). Altogether, the empirical evidence suggests that adherence to an honor code or related conduct norms does not account for the victim-offender overlap.

\section{Control Explanations}

Varieties of control theory have been prominent in empirical research on the victimoffender overlap. Control theories assume that the pursuit of advantage and avoidance of pain guides all human behavior. Because acts of force or fraud for private reasons are likely to be opposed by the target and society, whether people commit crime or not 
depends on the disincentives the decision-maker faces. Different variants of control theories have, as Gottfredson \& Hirschi (1990). observed, emphasized physical or natural restraints, legal punishments, and moral sanctions. Their version of self-control theory focuses less on the sanctioning systems than the quality of the actor's decisionmaking habits when confronted with a choice that has foreseeable but uncertain risks. Gottfredson \& Hirschi (1990). assume that offenders are sensitive to target vulnerability and target vulnerability itself is a product of choice. A person with low self-control gives little thought to long-term consequences and thus is not likely to fear any sanctioning system that, at the moment of the decision, does not present an immediate and tangible risk.

Because the ability of the target to complicate the plans of the would-be offender can vary, understanding crime target decision-making becomes scientifically important. Targets sometimes provoke their offenders by behaving inappropriately or provocatively (Luckenbill 1977, Schreck et al. 2021). Targets also prefer activities that are gratifying but that bring them into proximity with other offenders or make their desires less difficult to accomplish (chreck et al. 2002, Turanovic \& Pratt 2019). The assumptions of control theory prove useful for predicting patterns in precautionary behavior against crime and thus the victim-offender overlap. Because precautions reflect concern about a future uncertain event, the concept of self-control becomes relevant to understanding target decision-making (Schreck 1999, Turanovic \& Pratt 2019). A person who has self-control is more likely to respect how an otherwise gratifying decision might result in increasing their own vulnerability to crime and refrain from the action or mitigate the risk with precautionary measures. For instance, Felson and colleagues' (2018). study of inmates and their contacts in the community found that self-control reduced the tendencies of respondents to engage in verbal aggression, which lowered their involvement in violent encounters. Similarly, drinking alcohol heavily can bring pleasant sensations to the user, but drunkenness can also annoy others in various ways and leave one unable to resist an attacker. Those with self-control are less likely to drink and then fall victim (Franklin 2011) and less likely to engage in aggressive behavior. A person with low self-control, in contrast, will engage in the gratifying behavior and then hope it all works out.

What do the assumptions of social control theory hold for predictions about the victimoffender overlap? Any relationship between offending and victimization theoretically is a product of weak social bonds or low self-control. This prediction rests on the assumption that offending and victimization are common outcomes of weak social 
controls. Prior research has found that low self-control predicts victimization and offending but does not explain the relationship between them (e.g., Schreck 1999). Similarly, impulsivity and related indicators of self-regulation explain a portion of the association between victimization and offending but do not reduce it to zero (Loeber \& Farrington 2011, Ousey et al. 2011). For such tests, it is important for researchers to consider how control affects situational choice. In self-control theory, although targets act upon the situation, the situation also acts upon them (Gottfredson 2011). Rational choice theories, such as the routine activities and lifestyles approaches, therefore, are logical complements to the control perspective (Hirschi 1986).

\section{Routine Activities and Lifestyles Perspectives}

Since the early 1980s, the routine activities and lifestyles perspectives (Cohen $\boldsymbol{\&}$ Felson 1979, Hindelang et al. 1978) have occupied an important position in discussions about the explanation for the victim-offender overlap. The prominence of this perspective has much to do with the availability of victimization self-reports from broad cross sections of survey respondents. Data from large victimization surveys, notably the National Crime Survey-now National Crime Victimization Surveyprovided detailed images of the situational characteristics of violent events (see Lauritsen \& Laub 2007). What remains obvious today is that victims and offenders tended to resemble one another demographically and share similar lifestyles; moreover, vulnerability to violence is not distributed evenly throughout the population (Hindelang et al. 1978). Certain activities and lifestyle choices organized around leisure, domestic priorities, material need, and productivity significantly enhance a person's vulnerability and attractiveness as a target for violence (Lauritsen et al. 1991). The routine activities and lifestyles perspectives take as their focal subject of interest situational conditions-traceable to macrolevel social organization, including gender and class stratification-that govern differential exposure to settings where risk of victimization is high.

According to this perspective, demographic differences in victimization possibility result from a variation in lifestyles and routine activities that place individuals in degrees of proximity to motivated offenders and capable guardians (Cohen \& Felson 1979). Gottfredson (1981). presented justification for merging control theory with routine activities/lifestyles models on account of the evidence of the victim-offender overlap. According to Gottfredson (1981, pp. 725-26), "one of the central building blocks of the lifestyles concept has been the discovery that the factors most closely 
associated with victimization are factors which have also been found to be associated with offending." Rejecting assumptions about the motivating influence of normative processes implied in subcultural models, Gottfredson (1984, p. 17) argued, instead, that "there is a lifestyle for some that includes high probabilities of misfortunes, victimization and offending, due to perhaps where they live, where they go, and with whom they associate." He contended that the conventional bonds that inhibit offending also reduce exposure to motivated offenders by limiting activities in unguarded settings, thereby also reducing vulnerability.

Altogether, interpretations of the routine activities and lifestyles perspectives hold that victimization and offending are similarly determined by differential exposure to violence-conducive situations and, therefore, the association between them is probably spurious. Controlling for theoretically relevant exposure variables should reduce the positive correlation to zero. Several studies have found the statistical association between offending and victimization remains strong despite adjustments for a variety of variables measuring risk exposure in different social domains (see Averdijk $\underline{\boldsymbol{\&}}$ Bernasco 2015, Sampson \& Lauritsen 1990, Shaffer \& Ruback 2002). Moreover, criminal activity is shown to have a stronger effect on victimization risk, and vice versa, than demographic measures and many variables central to the routine activities and lifestyles perspectives (e.g., Felson et al. 2018, Jensen \& Brownfield

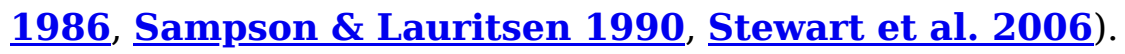

Scholarly efforts to test the assumptions regarding the etiology of the overlap from the perspective of the routine activities and lifestyles framework must confront certain methodological and substantive puzzles (Berg\&\& Mulford 2020). For one, most researchers rely on rather blunt frequency indicators of the average amount of time individuals report spending in various activities (e.g., frequency of nights out) with presumably different levels of risk for crime and violence, whether days, weeks, or months. These frequency indicators are not aligned with incidents of criminal offending or victimization. Largely missing from this work then are situation-specific measures that indicate precisely what the person was doing and where and with whom they were doing it during the exact time frame of the crime event. Space-time budget methods are suited to close some of this measurement gap (see Wikström et al. 2012b). Second, the narrow focus on the crime risk associated with conventional lifestyles or activities must resolve the theoretical possibility that criminal offending itself may be a risky lifestyle. Jensen \& Brownfield (1986, pp. 86-87) have argued that standard interpretations of the routine activities and lifestyles perspectives created an artificial dichotomy between victims and offenders. They criticized this 
perspective for adopting a "passive interpretation of lifestyles as enhancing victimization only through exposure and guardianship." According to Jensen \& Brownfield (1986) , criminal offending may be a routine activity or lifestyle for the following reasons: (a) Offenders often associate with others involved in crime; $(b)$ this exposure thereby increases one's contact with situations and other individuals that heighten victimization risk; and $(c)$ because criminal offenders can be targeted with impunity without the threat of legal sanction, they are vulnerable to violent reprisals from past victims (see Berg \& Felson 2016, Sparks 1982). Third, insufficient attention has been given to the possibility that any effects of routine activities and lifestyles variables on offending and victimization might result from the fact that individuals select into circumstances where crime potential is high (Felson et al. 2013). Some or all the effects of routine activities would then be spurious by-products of an underlying element of choice or risk propensity. This issue intersects with the substantive challenges of selection bias.

\section{Social Interactionist-Situational Perspective}

Most research on the victim-offender overlap relies on individual-level designs that examine data on the frequency of acts of self-reported victimization and offending. The same design technique is applied to measure other theoretically relevant explanatory variables (e.g., Shaffer \& Ruback 2002). These approaches are well suited to test hypotheses derived from explanations of individual differences in risk for violence involvement. There has been little in the way of theorizing about the situational mechanisms underlying the association between violent offending and victimization. The absence of such work has not gone unnoticed. Roughly three decades ago, Lauritsen and colleagues (1991, p. 288) argued that information on "the situational dynamics of juvenile offending and victimization would be helpful...the lack of such information has hampered the development of theory and policy for victims of crime."

Berg \& Felson (2020) . recently developed a social interactionist framework through which to understand the emergence of the association between violent offending and victimization at the situational level (Berg_\& Felson 2016). Their model, inspired by a rational choice perspective (Tedeschi \& Felson 1994), relies on social psychological principles (e.g., Goffman 1978) to understand how verbal disputes escalate. Berg_\& Felson (2020) focus on the escalation of disputes and the situational factors that distinguish nonviolent from violent disputes. Their model recognizes that most 
homicides and acts of violence result from moralistic disputes over issues of right and wrong, but most disputes never result in physical violence.

Which adversary becomes the victim and which the offender cannot be readily predicted at the outset of a dispute (Luckenbill 1977). Face-saving concerns and audience effects, among other social psychological factors, determine the salience of moralistic violations and how antagonists respond to them, including whether they choose violent actions (see Tedeschi \& Felson 1994). According to Berg $\boldsymbol{\&}$ Felson's (2020) argument, assessing how certain people typically manage interpersonal disputes-for example, whether they threaten or negotiate solutions-may illuminate why the same individuals rotate between the roles of victim and offender. Researchers tend to categorize individuals as either victim or offender according to their final role in the dispute, when in many instances the offender is not the only or first person to engage in violence. The actor who was initially the offender in a dispute may have become the victim as it escalated, thereby contributing to the victim-offender overlap. This approach ignores the escalation process and thus the behavioral tendencies that actors bring to disputes.

Berg \& Felson (2016). have suggested that serious offenders and nonoffenders possess different tendencies when they engage in dispute-related behaviors, and these tendencies may account for why offenders have relatively higher rates of victimization. First, offenders have a greater tendency to be provocative during disputes-issuing insults and threats that elicit counterattacks-and these same individuals are less inclined to engage in remedial actions in the form of apologies, accounts, and excuses. Offenders therefore are unlikely to possess the inhibitions that are known to diffuse everyday conflict (Barlett et al. 2016). Second, disputes involving offenders are more likely to occur in the presence of partisan third parties who encourage rather than mediate the conflict. If third parties encourage adversaries, their actions theoretically increase the odds of conflict escalation ( increases conflict escalation because it leads people to become hostile, violate social norms, be less aware of risks, and be less inclined to use precautions than when sober. Using a sample of inmates from Pennsylvania and their contacts in the community, Berg\& Felson's (2020). analysis of verbal and violent conflicts indicated that provocations, intoxication, remedial actions, and third-party presence partly explained why offenders had a substantially elevated risk of becoming involved in violent incidents and being victimized. Offenders possessed inadequate prosocial skills that, when combined with their provocative tendencies and the presence of partisan third parties, resulted in their frequent involvement in violent confrontations. 
Clear in the above body of theorizing is the contrast between the positivist theories (subculture) of crime and those derived from the choice perspective (e.g., routine activities/lifestyles, control, and social interactionist). These accounts have provided a bevy of competing hypotheses about the nature and scope of the overlap as well as the mechanisms responsible for the genesis of the overlap. What is obvious is that positivist theories suggest basic facts surrounding the overlap that are different than what is suggested by frameworks deduced from the choice paradigm.

\section{THE MEANING OF THE OVERLAP FOR THEORY DEVELOPMENT}

A complaint sometimes raised in criminology is that no theory has ever been falsified (Bernard 1990). There is instead an illusion of progress as theories fall out of favor, are forgotten, and then experience resurgences in popularity (Hirschi 1989). Crime prevention policies reveal a similar cyclical historical pattern. All this suggests that theory falsification and meaningfully novel policy cannot be readily achieved solely by increasing the amount of empirical research. Closer inspection of a theory's internal logic, we believe, provides a solution. The consistencies in how crime theories have approached the victim-offender overlap reflect their internal logic and define whether it is even possible for them to treat the overlap as a basic fact. Whether theories can or cannot view the overlap as a fact of crime is not a trivial matter and affects how theories of crime must evolve going forward if they are to remain plausible.

All theories of crime contain logical structures that assign importance and meaning to empirical facts, such as the victim-offender overlap. Although criminological theories may appear on the surface to offer little beyond what they say about the offender, each tacitly endorses a conception of human nature such as the presence of natural selfinterest (oshier 1989). Because human nature applies to all participants in a criminal incident, it allows a theorist to go beyond the offender and toward the explanation of the target or the victim. The target's actions and decision-making tendencies originate from the same basic nature as the offender. In this way, all theories of crime contain an implicit theory of victimization, although not necessarily a theory predicting an overlap (Schreck \& Berg 2021). Put differently, whatever qualities the theorist would deny or bequeath to the offender, they must do the same to the target. Integrity to a theory's internal logic then forces specific predictions about victimization and vulnerability.

We argue that the internal logic of an otherwise plausible theory of crime can force it to make incorrect predictions about the basic facts surrounding the victim-offender overlap. Arguably, this results in some theories being falsified, and policymakers 
should thus look to other theories for crime prevention solutions. Here, our intent is not to retrace the hypotheses regarding the victim-offender overlap implied in leading crime theories but to discuss the implications of the overlap more broadly for the logic of the theory's internal structure.

The assumptions of positivist theories of crime, such as subcultural theory, require that the victim-offender overlap is conditional or accounted for by separate theories of victimization and offending. It is not possible in these theories to assign importance to the target. Positivist theories of crime imply that the meaning of victimization to the target as an event is variable and dependent on exposure to prior causes, making it effectively arbitrary. What discrete events count as victimization must therefore vary across time and space and between individuals. Given that crime likewise varies in meaning to the positivist perspective, this necessitates that any overlap between victims and offenders must be a normative coincidence, not a basic fact.

Turning now to the value of victim precautionary behavior, positivist theories of crime have difficulty arguing that offenders respond in any consistent way to precautionary behavior (see Anderson 1999). Offenders are acting according to definitions and scripts endorsed by the local culture (e.g., street code) rather than some objective external reality. In fact, cultural norms may endorse the view that acts representing defensive behavior to one group symbolize provocation to the other, leading to even worse outcomes. As Schreck \& Berg_(2021). argued, this means that to a positivist theorist the offender's motivation is what defines the vulnerability of the target for crime. That is, vulnerability has less to do with the target objectively simplifying the offender's capacity to perpetrate a criminal offense, like walking alone from a bar at night while inebriated, and instead almost everything to do with the offender's acquired subjective triggers. For these reasons, we believe that theoretical (or substantive) positivism is the source of the offender focus in criminology and the crime prevention policies that are overwhelmingly centered on altering the offender.

Any theory that denies the individual natural self-interest and rationality, we believe, is thus unable to produce a theory of victimization consistent with the facts. A voluminous body of research shows that target behavior affects the offender's choices (Hough 1987, Schreck et al. 2021, Tedeschi \& Felson 1994, Wright \& Decker 1997). A successful theory of crime must be able to assign independent causal value to target actions, and this is possible by assuming that vulnerability is an objective quality and that offenders everywhere can recognize and act upon it. A successful theory of crime must anticipate the empirical fact of the victim-offender overlap and 
cannot predict that people who are victims and offenders differ across groups and locations. As a result of this inconsistency with the facts, the overlap places positivist theories in a bind. Moreover, policy recommendations based on positivist theory-like changing antisocial norms-become suspect.

The class of control or choice theories appears best positioned to incorporate the research findings on victimization and thus the fact of the victim-offender overlap into their internal logic. To the degree that humans contemplating crime are responsive to certain, swift, and severe danger, it becomes readily apparent that the target is a more obvious place to begin for understanding crime than any of the other sources of control. The actions of the target in the moment and afterward substantially determine whether the other sanctioning systems become involved. As Farrell et al. (1995, p. 386) note, choice models accept that "sound judgments of victim suitability and guardian proximity defines a reasoned choice. Insofar as these factors are neglected, offending cannot be deemed rational." Indeed, central to the routine activities and lifestyle theories (e.g., Hindelanget al. 1978) and social interactionist models (e.g., Berg\& Felson 2020) is an offender who is responsive to target vulnerability in an objective sense-offenders everywhere prefer targets that are desirable in the moment, that are within reach, and that seem to them poorly protected.

With this realization, the target's decision-making becomes a matter of importance potentially equal to that of the offender. The target-the potential victim-can conceivably affect all three basic requirements for crime: They can make themselves unattractive to offenders, keep themselves or their belongings out of reach, and take whatever action necessary to increase the difficulty and risk for the offender. The tendency of individuals to ignore long-term but easily foreseeable consequences makes risky but otherwise gratifying actions appear more attractive than being safetyminded. For instance, self-control expresses itself in vulnerability-enhancing behavior (i.e., risk for victimization) as well as criminal behavior (Felson et al. 2018 , Schreck et al. 2021). A corollary to this is the fact that those low in social control also tend to report weak ties of attachment to parents or school. Although caring about no one's opinion frees a person to commit crime (Hirschi 1969), it also eliminates potential guardians that protect against victimization (Felson 1986, Schreck \& Fisher 2004). In this way, the internal logic of control theory can account for not only the victimoffender overlap but also the shared correlates.

To be sure, in presentations of control, routine activities and lifestyles, and self-control theories, the victim's importance to the crime event is evident. These models assume 
that offenders are deterred by immediate and obvious risk; the appeal of crime is its promise of easy and risk-free reward. In self-control theory, the target spoils that in various ways. "Potential victims seek to protect themselves from the inclinations of others. They...lock doors, hide valuables, ...[and] avoid provocation" (Gottfredson \& Hirschi 1990, p. 18). Or, put differently, control theory does not assign major responsibility for the criminal act to the inclination of the offender. Rather, both offenders and potential victims interact, and in control theories, the target-by their own effort and behaviors-can deny would-be offenders the opportunity to act. Even when the offender recognizes a target, the targets can create enough uncertainty about a crime's success that the offender chooses to do something else.

Likewise, the internal logic of routine activities and lifestyles models (Cohen \& Felson 1979) can accommodate the facts of the victim-offender overlap. Like control theory, these models assume a rational self-interested actor who has no specific motivation for crime. The inducement to act arises from the situation, and the target is a critical component of the situation. Offenders sense vulnerability intuitively, without the necessity of exposure to prior antecedents or external social or biological causes. Similarly, the victim also has the scope to act to shape and respond to any risks in a situation. As Hindelang et al. (1978, p. 268) argued, certain people, by virtue of their lifestyles, are more inclined to be in situations that would provide sufficient opportunities to behave in ways that "precipitate or escalate violent victimization." These theoretical notions centered on victim choice guide some of the explanatory research on the repeat victimization (e.g., Tseloni \& Pease 2003). Given that control, social interactionist, and routine activity and lifestyles theories are indistinguishable in their base logic (Hirschi 1989, Roshier 1989), we combine them for simplicity under the broader heading of the "choice perspective."

\section{THE MEANING OF THE OVERLAP FOR PRINCIPLES OF CRIME PREVENTION POLICY}

Altogether, choice theories urge policymakers to appreciate the importance of both the offender's and the crime target's decision-making, who in many cases may be one and the same, to reduce crime. But there is an important, albeit tense, relationship between a theory of crime and the expression of crime control policy. When scientific methods available to criminology are unable to discard theory, and when criminology only gradually accepts meaningful new facts, questionable policies survive. Perhaps the victim-offender overlap offers the impetus for moving forward. Because much of criminology is focused on the offender, this prompts a library of policy mostly 
advocating the offender's treatment or punishment. With few exceptions (e.g., Farrell et al. 2014, Wikström et al. 2012a), most criminological models justifying such approaches to crime control grant the offender's target a very limited role as an active decision-maker (Schreck \& Berg_2021). Programs focused on modifying target behavior become peripheral, and so there can be little surprise that the target's decision-making is largely neglected in influential crime policy discussions (e.g., Kleiman 2009). Furthermore, a disincentive to exploring target behavior is that the researcher might be wrongfully accused of blaming the victim for "choosing" the circumstances that create their own misfortunes, which is an accusation that confuses matters of scientific cause with blame.

The population at large takes a different view of its own relevance in preventing crime: The prevalence of at least some form of precautionary behavior is borderline universal (Meier \& Miethe 1993, Schreck et al. 2018). This does not mean, however, that people are always able or willing to take precautions, will be consistent in their use, and can accurately gauge what is appropriate to the circumstances, or that the precautions available to them are effective. From our vantage point, choice theories are useful because they seem to offer principles to guide policy in a way that is responsive to the human side of precautionary behavior. In choice theory, offenders generally act only if they believe they can manage the situation. The target's actions in many situations can make physical, legal, or social sanctions likely to follow, thus deterring the offender.

What does the victim-offender overlap, when understood through the logic of choice theories, suggest regarding the general principles of crime prevention policy? First, the overlap indicates there may be dual benefits to early-life behavioral interventions designed to create lasting self-restraint and appreciation of the immediate and longterm consequences of decisions. A focus on the childhood family environment provides theories of choice with a set of expectations for crime control policy that does not involve the machinery of deterrence. More specifically, control theories, for instance, focus heavily on the restraining influences created by strong personal relations in childhood (e.g., Gottfredson \& Hirschi 2020). Lasting efforts at preventing victimization and offending can be achieved by affecting the strength of socialization in early childhood. Supporting this approach, research has found that family processes, including socialization, reliably predict youth victimization (Barker et al. 2008, Esbensen et al. 1999, Loeber \& Farrington 2011). Evaluations of interventions focused on children's social skills have also reported promising findings. For instance, child-parent training programs have shown to be effective at reducing 
antisocial behavior and promoting positive parenting competencies (Heckman 2007; e.g., Olds 2007). Such intervention programs boost the long-term capacity of individuals to foresee risk, appreciate immediate and distant costs, and practice consistent restraint-each of which underlies acts of safety-minded behavior as well as crime. Research on the Pittsburgh Youth Study has shown that, focused on boys (ages 7 to 13), such interventions with a $30 \%$ success rate would reduce the burden of homicide victimization and offending by nearly one-third (Loeber \& Farrington 2011). Given that the designs of most early-life intervention programs are focused on reducing criminal behaviors, evaluators should also measure their effectiveness at reducing tendencies that promote vulnerability to victimization. This approach could go a long way to reducing the occurrence of the victim-offender overlap.

Second, the choice model interpretation of the victim-offender overlap suggests that we can expect that the same fundamental principles guiding people to commit crime also guide immediate precautionary behaviors-behaviors that reduce victimization risk. That is to say, if people engage in force or fraud because it is advantageous, then people also protect themselves against force or fraud because it is advantageous. If people refrain from crime because they are restrained or the crime is impossible, so too do people refrain from precautionary behavior. In other words, those anticipating a threat will protect themselves against crime until restrained by their resources, available courses of action, or competing notions of self-interest. Although no one wants to experience victimization, the assumptions of choice theories bring to light a pair of issues. For one, many defensive actions incur expense, and people may have to triage limited personal resources because of structural conditions that restrict where they can live, work, and interact. For another, safety, although desirable, must compete with other beneficial or gratifying actions and with competing interests in the moment. This reality is recognized in choice theories in which wider structural constraints place limits on the abilities of individuals to manage routine risk (Hindelanget al. 1978). Policy may or may not be in a position to dramatically alleviate poverty or inequality, although research can help identify where existing resources can best be allocated.

Turning to understanding the human aspect of taking precautions in view of crime prevention policy, it seems the decision by potential targets to use available precautions depends on the principles of certainty, swiftness (or ease), and severity (or gratifiability). First, people are more likely to use precautions the more certain they are that they will be targeted for victimization. The fear-of-crime literature is replete with research showing how disorder and incivilities, and witnessing and experiencing victimization, promote feelings of discomfort and induce safety-minded behavior 
(Ferraro 1995, Rountree 1998, Schreck et al. 2018). Recent research on adolescents finds that fear of crime is negatively related to violent offending and victimization-thus operating as a shared correlate (Melde et al. 2016). Second, a person is more likely to see precautionary behavior as worthwhile to the degree that it is quick or easy (swift). Precautions requiring less personal investment in time and effort increase the probability that they will be used by people consistently, as will those precautions that involve less risk. Third, people prefer precautions that produce immediate and obvious reward. Any safety-minded behavior is gratifying simply by alleviating anxiety and promoting a sense of well-being (Perloff 1983). However, the purchase of defensive firearms also includes benefits like recreational possibilities, community with other owners, and feelings of power ( $\underline{\text { Schreck et al. 2018}}$ ). All three elements-certainty, ease, and gratifiability_probably interact in complex ways. Schreck \& Berg_(2021), for instance, referenced how owning firearms may be pleasurable to some, but others are deterred by the concern that firearms are not easy to own, as they are expensive, difficult to store safely, and dangerous. Yet when the certainty of victimization seems high, people may be willing to incur such costs anyway. This possibility is evident in qualitative accounts of street violence (Jacobs \& Wright 2006) and surveys reveal that the perceived risk of victimization is a main

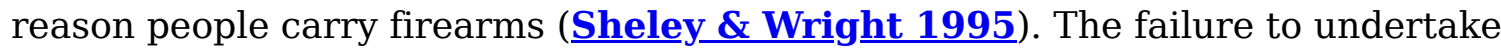
precautionary behavior thus must be understood as a rational decision; public policy must incentivize safety-mindedness, commit to simplifying and reducing the cost of proven effective methods, or communicate the risks and costs of victimization in a way that leaves an impression on the potential target.

The above three principles reflect general rules for precautionary behavior that are derived from the assumptions of choice theory, but the victim-offender overlap adds additional useful information for any policy attempting to guide the individual target's decision-making: Precautions against victimization presuppose that the individual can foresee an uncertain future event and then act accordingly to mitigate risk. For instance, if low self-control is the habitual tendency to ignore distant consequences and connected in obvious ways to offending and poor decision-making, then policymakers can anticipate that the natural bent of individuals with such qualities will lead them to: 


\begin{tabular}{|c|c|}
\hline " & $\begin{array}{l}\text { Be fixated on whatever immediately gratifying course of action they are presently } \\
\text { engaging in, such as drinking heavily or being disputatious, even if the action is } \\
\text { provocative to others and creates significant vulnerabilities. Insensitivity to risk } \\
\text { and costs mutes the certainty of victimization, and thus the desire to take } \\
\text { corrective action, until victimization happens. }\end{array}$ \\
\hline - & $\begin{array}{l}\text { Be more easily deterred from safety-minded behavior, everything else being equal, } \\
\text { by the immediate difficulty of the task and inconvenience with respect to gratifying } \\
\text { other interests. Someone impatient with effort is probably more likely to defer the } \\
\text { hassle of precautionary behavior as far into the future as possible, usually until the } \\
\text { moment they realize they are the target (e.g., Jacobs \& Wright 2006). }\end{array}$ \\
\hline - & $\begin{array}{l}\text { Be highly attracted to available precautions that are inherently and immediately } \\
\text { gratifying or pain-avoiding, without necessarily considering whether the precaution } \\
\text { is effective, dangerous to themselves or others, or appropriate to the } \\
\text { circumstances. Someone insensitive to risk will thus find firearms attractive } \\
\text { because of the status that they bring and perceptions of their apparent deterrent } \\
\text { value, all while ignoring their dangerousness. }\end{array}$ \\
\hline
\end{tabular}

An understanding of the victim-offender overlap can thus explain why otherwise reasonable precautionary strategies-such as enhancing indirect informal social control in a community or improving levels of guardianship and increasing police presence-may fail among those individuals with the highest risk of victimization. Although monitoring someone can be protective, if that person does not have an immediate appreciation for the costs of their actions and is unlikely to foresee victimization, they will not value the increase in their own safety. This suggests that indirect means to encourage safety-mindedness can work to reduce crime and violence. Furthermore, direct approaches to encourage and inculcate precautionary behaviors may also yield stable reductions in crime and victimization even among highrisk adults. For instance, intervention programs that foster improved awareness of the consequences of choices among high-risk adults, e.g., those that bolster problemsolving skills, might reduce decisions that cause disputes to escalate (Berg_\& Felson 2016). A variety of such programs that focus on promoting restraint have been implemented in correctional settings and produced beneficial results (see Bush et al. 2011, Lowenkamp et al. 2009). 


\section{CONCLUSION}

Everywhere researchers have looked, victimization is positively correlated with offending. The relationship between victimization and crime is not dependent upon age, race, gender, or nation, or because of any substantive correlate criminology has yet produced. Neither do longitudinal examinations show the overlap fundamentally changing with time. The correlates of victimization and offending appear everywhere to be very similar. Evidence for the victim-offender overlap extends as far back as there are reliable data on victimization and offending. More than sixty years of study on the overlap has revealed an impressive consistency of results. The methodological challenges-e.g., the issues of temporal ordering offending, selection bias, and construct measurement-may not seem immediately solvable, but neither would their resolution present any difficulty for the basic pattern of findings.

The challenge criminology faces in processing the meaning of these findings for theory and policy is, however, a solvable problem. In fairness, the overlap presented a puzzle that criminology was ill-equipped to address. By the time the initial findings of an overlap became available, criminology was already committed to developing theories based on positivist assumptions. These assumptions differentiated offenders from their victims, so the default position was that each group possessed distinct correlates and characteristics. These assumptions also made the actions of targets and victims scientifically unimportant relative to the offender's exposure to causal pathological conditions; the offender's motivation is all-important, and a motivated offender always finds a way. Positivist accounts, mainly subcultural theory, proceeded to explain it according to these principles. What they produced was rather inconsistent with the facts, and their internal logic offers little promise that these theories can be made to work. In this way, the victim-offender overlap has a significant role in ruling out the validity of many theoretical perspectives on crime and their related policies. The choice perspective in criminology took a different path, producing a range of theories built upon victim data and with full awareness of the victim-offender overlap: These theories gave the target a role, and they were able to use the victim-offender overlap to specify how the same mechanisms that produce crime also produced distinctive qualities in target decision-making. The fact of the overlap encourages criminology to view research on crime-target decision-making as a matter of scientific urgency.

Given the facts, the choice perspective-routine activities and lifestyles, control, and social interactionist theories-appears to be the best equipped to account for the overlap. In our view, future research should draw from these models to derive testable 
hypotheses and develop criminology's theoretical toolkit. Whereas research looking at the generality of the overlap is no longer needed, we believe these theories offer an intriguingly novel path forward for explaining and solving the problem of crime. We presented as examples a substantive and policy agenda that we encourage criminology to consider and pursue. The victim-offender overlap research indicates that early childhood programs likely produce a twofold benefit of reducing criminal offending and victimization. Also, research should develop a deep understanding of target decision-making and the offender's responsiveness to it. On the policy side, there are advantages to emphasizing the target in crime control policy beyond crime reduction. Choice theory, for instance, expects a set of policies that originate in early childhood with manifest benefits for improving long-term judgment and restraint, thus reducing the necessity of formal sanctions administered by the criminal justice system.

Criminology is presently concentrated on various policy ideas centered upon the offender such as focused deterrence (e.g., Fox \& Novak 2018) and programs designed to change group norms to suppress cycles of urban violence (e.g., Slutkin et al. 2015). A common thread is that each elevates, at least in part, the need for law enforcement to curb the burden of violent offending. We do not argue that the crime target in all situations has complete autonomy to foil the offender's desire. We do, however, argue that the influence of the target on acts of crime is certainly not zero. This possibility places an upper limit on the contagion of violent events. The fact of the victim-offender overlap therefore indicates that the boundaries of effective crime control policy-its ability to reduce victimization and offending-need not necessarily include the state. It seems that a principal lesson of the overlap argues that the achievement of crime control among high-risk populations is possible through compensating and supporting the natural limitations of decision-making. This, too, can be accomplished without a fundamental retooling of social inequalities. If criminology has long decried the inequity arising from the machinery of the criminal justice system (e.g., Wellford 1997), policies aimed at maximizing safety-mindedness efficiently sidestep this costly system by ensuring that potential criminals have fewer opportunities to offend in the first place and thus targets incur less suffering through victimization.

\section{Acknowledgements}

We thank Joan Antunes, Michael Gottfredson, Beth Hardie, Travis Pratt, and Ethan Rogers for their comments on earlier drafts of this manuscript 


\section{LITERATURE CITED}

Anderson E. 1999. Code of the Street: Decency, Violence, and the Moral Life of the Inner City. New York: Norton

Averdijk M, Bernasco W. 2015. Testing the situational explanation of victimization among adolescents. J. Res. Crime Delinquency 52:151-80

Barker ED, Boivin M, Brendgen M, Fontaine N, Arseneault L, et al. 2008. Predictive validity and early predictors of peer-victimization trajectories in preschool. Arch. Gen. Psychiatry 65(10):1185-92

Barlett C, Witkower Z, Mancini C, Saleem M. 2016. Breaking the link between provocation and aggression: the role of mitigating information. Aggress. Behav. $42(6): 555-62$

Beckley AL, Caspi A, Arseneault L, Barnes JC, Fisher HL, et al. 2018. The developmental nature of the victim-offender overlap. J. Dev. Life-Course Criminol. 4:2449

Berg MT. 2012. The overlap of violent offending and violent victimization: assessing the evidence and explanations. In Violent Offenders: Theory, Research, Policy, and Practice, ed. M Delisi, PJ Conis, pp. 17-38. Burlington, MA: Jones \& Bartlett Berg MT, Felson R. 2020. A social interactionist approach to the victim-offender overlap. J. Quant. Criminol. 36:153-81

Berg MT, Felson RB. 2016. Why are offenders victimized so often? In The Wiley Handbook on the Psychology of Violence, ed. C Cuevas, C Rennison, pp. 49-65. Malden, MA: Wiley

Berg MT, Loeber R. 2011. Examining the neighborhood context of the violent offending- victimization relationship: a prospective investigation. J. Quant. Criminol. 27:427-51

Berg MT, Mulford CF. 2020. Reappraising and redirecting research on the victimoffender overlap. Trauma Violence Abuse 21:16-30

Berg MT, Stewart EA, Schreck CJ, Simons RL. 2012. The victim-offender overlap in context: examining the role of neighborhood street culture. Criminology 50:359-90 
Bernard TJ. 1990. Twenty years of theory testing: What have we learned and why? J. Res. Crime Delinquency 27:325-47

Bush J, Glick B, Taymans J, Guevara M. 2011. Thinking for a Change: Integrated Cognitive Behavior Change Program Version 3.1. Washington, D.C.: US Dep. Justice

Carlsson C. 2013. Masculinities, persistence, and desistance. Criminology 51:661-93

Chen X. 2009. The link between juvenile offending and victimization: the influence of risky lifestyles, social bonding, and individual characteristics. Youth Violence Juv. Justice 7(2):119-35

Cohen LE, Felson M. 1979. Social change and crime rate trends: a routine activity approach. Am. Sociol. Rev. 44:588-608

Cook PJ. 1986. Demand and supply of criminal opportunities. Crime Justice 7:1-27

Cooney M. 1998. Warriors and Peacemakers: How Third Parties Shape Violence. New York: NYU Press

Daquin JC, Daigle LE. 2020. The victim-offender overlap in prison: examining the factors associated with group membership. J. Interpers. Violence. In press. https://doi.org/10.1177/0886260519898427

Esbensen FA, Huizinga D, Menard S. 1999. Family context and criminal victimization in adolescence. Youth Soc. 31(2):168-98

Enzmann D, Kivivuori J, Marshall IH, Steketee M, Hough M, Killias M. 2017. A Global Perspective on Young People as Offenders and Victims: First Results from the ISRD3 Study. Cham, Switz.: Springer

Farrall S, Calverley A. 2006. Understanding Desistance from Crime: Theoretical Directions in Resettlement and Rehabilitation. Berkshire, UK: Open Univ. Press

Farrell G, Phillips C, Pease K. 1995. Like taking candy: Why does repeat victimization occur? Brit. J. Criminol. 35:384-99

Farrell G, Tilley N, Tseloni A. 2014. Why the crime drop? Crime Justice 43(1):421-90

Farrell G, Tseloni A, Mailley J, Tilley N. 2011. The crime drop and the security hypothesis. J. Res. Crime Delinquency 48(2):147-75 
Felson M. 1986. Linking criminal choices, routine activities, informal control, and criminal outcomes. In The Reasoning Criminal: Rational Choice Perspectives on Offending, ed. DB Cornish, RV Clarke, pp. 119-28. New York: Springer-Verlag Felson RB, Berg MT, Rogers EM, Krajewski A. 2018. Disputatiousness and the offendervictim overlap. J. Res. Crime Delinquency 55:351-89

Felson RB, Savolainen J, Berg MT, Ellonen N. 2013. Does spending time in public settings contribute to the adolescent risk of violent victimization. J. Quant. Criminol. 29:273-93

Ferraro K. 1995. Fear of Crime: Interpreting Victimization Risk. Albany, NY: SUNY Press

Fox AM, Novak KJ. 2018. Collaborating to reduce violence: the impact of focused deterrence in Kansas City. Police Q. 21(3):283-308

Franklin CA. 2011. An investigation of the relationship between self-control and alcohol- induced sexual assault victimization. Crim. Justice Behav. 38:263-85

Goffman E. 1978. The Presentation of Self in Everyday Life. London: Harmondsworth Gottfredson MR. 1981. On the etiology of criminal victimization. J. Crim. Law Criminol. 72:714-26

Gottfredson MR. 1984. Victims of Crime: The Dimensions of Risk. London: HM Station. Off.

Gottfredson MR. 2011. Sanctions, situations, and agency in control theories of crime. Eur. J. Criminol. 8:128-43

Gottfredson MR. 2021. Modern control theory, lifestyle and criminal victimization. In Revitalizing Victimization Theory: Revisions, Applications, and New Directions, ed. TC Pratt, JJ Turanovic, pp. 56-76. New York: Routledge

Gottfredson MR, Hirschi T. 1990. A General Theory of Crime. Palo Alto, CA: Stanford University

Gottfredson MR, Hirschi T. 2003. Self-control and opportunity. In Control Theories of Crime and Delinquency, ed. CL Britt, MR Gottfredson, pp. 5-19. New York: Routledge 
Gottfredson MR, Hirschi T. 2020. Modern Control Theory and the Limits of Criminal Justice. New York: Oxford

Heckman JJ. 2007. The economics, technology, and neuroscience of human capability formation. PNAS 104:13250-55

Hindelang MJ. 1976. Criminal Victimization in Eight American Cities. Cambridge, MA: Ballinger

Hindelang MJ. 1981. Variations in sex race age specific incidence rates of offending. Am. Sociol. Rev. 46:461-74

Hindelang MJ, Gottfredson MR, Garofalo J. 1978. Victims of Personal Crime. Cambridge, MA: Ballinger

Hirschi T. 1969. Causes of Delinquency. Berkeley, CA: Univ. Calif. Press

Hirschi T. 1986. On the compatibility of rational choice and social control theories of crime. In The Reasoning Criminal: Rational Choice Perspectives on Offending, ed. DB Cornish, RV Clarke, pp. 105-18. New Brunswick, NJ: Transaction

Hirschi T. 1989. Exploring alternatives to integrated theory. In Theoretical Integration in the Study of Crime and Deviance, ed. S Messner, M Krohn, A Liska, pp. 37-49. Albany, NY: SUNY Press

Horowitz R. 1983. Honor and the American Dream. Chicago: Univ. Chicago Press Hough M. 1987. Offenders' choice of target: findings from victim surveys. J. Quant. Criminol. 3:355-69

Jacobs BA, Wright R. 2006. Street Justice: Retaliation in the Criminal Underworld. New York: Cambridge Univ. Press

Jensen G, Brownfield D. 1986. Gender, lifestyles, and victimization: beyond routine activity theory. Violence Vict. 1:85-99

John Jay Coll. Res. Advis. Group Prev. Reducing Community Violence. 2020. Reducing violence without police: a review of research evidence. Res. Eval. Cent. Rep., City Univ. New York, New York. https://johnjayrec.nyc/2020/11/09/av2020/

Junger M, Terlouw GJ, Van Der Heijden PG. 1995. Crime, accidents and social control. Crim. Behav. Ment. Health 5(4):386-410 
Kleiman MA. 2009. When Brute Force Fails: How to Have Less Crime and Less Punishment. Princeton: Princeton Univ. Press

Lauritsen JL, Heimer K. 2008. The gender gap in violent victimization. J. Quant. Criminol. 24:125-47[**AU: This reference is not cited in the text. Please add there or remove from here.**]

Lauritsen JL, Laub JH. 2007. Understanding the link between victimization and offending: new reflections on an old idea. Crime Prev. Stud. 22:55-75

Lauritsen JL, Laub JH, Sampson RJ. 1992. Conventional and delinquent activities: implications for the prevention of violent victimization among adolescents. Violence Vict. 7:91-108

Lauritsen JL, Sampson RJ, Laub JH. 1991. The link between offending and victimization among adolescents. Criminology 29:265-92

Loeber R, Farrington DP. 2011. Young Homicide Offenders and Victims: Risk Factors, Prediction, and Prevention from Childhood. Berlin: Springer Sci.

Loeber R, Kalb L, Huizinga D. 2001. Juvenile delinquency and serious injury victimization. Rep., Off. Juv. Justice Delinquency Prev., Washington, DC. https://www.ojp.gov/pdffiles1/ojjdp/188676.pdf

Lowenkamp CT, Hubbard D, Makarios MD, Latessa EJ. 2009. A quasi-experimental evaluation of thinking for a change: a "real-world" application. Crim. Justice Behav. 36:137-46

Luckenbill D. 1977. Homicide as a situated transaction. Soc. Probl. 25:176-86

Meier RF, Miethe TD. 1993. Understanding theories of criminal victimization. Crime Justice Rev. Res. 17:459-99

Melde C, Berg MT, Esbensen FA. 2016. Fear, social interactions, and violence mitigation. Justice Q. 33(3):481-509

Moffitt TE, Arseneault L, Belsky D, Dickson N, Hancox RJ, et al. 2011. A gradient of childhood self-control predicts health, wealth, and public safety. PNAS 108(7):2693-98

Moffitt TE, Robins RW, Caspi A. 2001. A couples analysis of partner abuse with implications for abuse-prevention policy. Criminol. Public Policy 1(1):5-36 
O SH. 2020. Street codes and school victimization: analyses of U.S. and South Korean students. PhD Thesis, Univ. Cincinnati, Cincinnati, $\mathrm{OH}$

Odgers CL, Caspi A, Broadbent JM, Dickson N, Hancox RJ, et al. 2007. Prediction of differential adult health burden by conduct problem subtypes in males. Arch. Gen. Psychiatry 64(4):476-84

Olds DL. 2007. Preventing crime with prenatal and infancy support of parents: the nurse-family partnership. Vict. Offenders 2(2):205-25

Osgood DW, Wilson JK, O’Malley PM, Bachman JG, Johnston LD. 1996. Routine activities and individual deviant behavior. Am. Sociol. Rev. 61(4):635-55

Ousey GC, Wilcox P, Fisher BS. 2011. Something old, something new: revisiting competing hypotheses of the victimization-offending relationship among adolescents. $J$. Quant. Criminol. 27(1):53-84

Papachristos AV, Wildeman C, Roberto E. 2015. Tragic, but not random: the social contagion of nonfatal gunshot injuries. Soc. Sci. Med. 125:139-50

Perloff LS. 1983. Perceptions of vulnerability to victimization. J. Soc. Issues 39(2):41-61

Reid JA, Sullivan CJ. 2012. Unraveling victim-offender overlap: exploring profiles and constellations of risk. Vict. Offenders 7(3):327-60

Reingle JM, Maldonado-Molina MM. 2012. Victimization and violent offending: an assessment of the victim-offender overlap among Native American adolescents and young adults. Int. Crim. Justice Rev. 22(2):123-38

Reisig MD, Holtfreter K. 2018. The victim-offender overlap in late adulthood. J. Elder Abuse Negl. 30(2):144-66

Reiss AJ Jr. 1981. Towards a revitalization of theory and research on victimization by crime. J. Crim. Law Criminol. 72:704-13

Rosenfeld R. 2018. Studying crime trends: normal science and exogenous shocks. Criminology 56(1):5-26

Roshier B. 1989. Controlling Crime: The Classical Perspective in Criminology. Chicago: Lyceum Books 
Rountree PW. 1998. A reexamination of the crime-fear linkage. J. Res. Crime Delinquency 35(3):341-72

Sampson RJ, Lauritsen JL. 1990. Deviant lifestyles, proximity to crime, and the offender-victim link in personal violence. J. Res. Crime Delinquency 27(2):110-39

Schreck CJ. 1999. Criminal victimization and low self-control: an extension and test of a general theory of crime. Justice Q. 16(3):633-54

Schreck CJ, Berg MT. 2021. What ideas of victimization and vulnerability mean for criminological theory: a logical appraisal. In Revitalizing Victimization Theory: Revisions, Applications, and New Directions, ed. TC Pratt, JJ Turanovic, pp. 15-55. New York: Routledge

Schreck CJ, Berg MT, Fisher BS, Wilcox P. 2018. That door you just kicked in was locked for your protection, not mine: developing and testing competing theoretical models of crime prevention behavior. J. Res. Crime Delinquency 55(2):316-45

Schreck CJ, Berg MT, Ousey GC, Stewart EA, Miller JM. 2017. Does the nature of the victimization-offending association fluctuate over the life course? An examination of adolescence and early adulthood. Crime Delinquency 63(7):786-813

Schreck CJ, Berg MT, Rogers EM. 2021. Predicting the probability of violence in actortarget relational dyads: self-control and interpersonal violence as mutual properties. Br. J. Criminol. https://doi.org/10.1093/bjc/azab014

Schreck CJ, Fisher BS. 2004. Specifying the influence of family and peers on violent victimization: extending routine activities and lifestyles theories. J. Interpers. Violence 19(9):1021-41

Schreck CJ, Stewart EA, Osgood DW. 2008. A reappraisal of the overlap of violent offenders and victims. Criminology 46(4):871-906

Schreck CJ, Wright RA, Miller JM. 2002. A study of individual and situational antecedents of violent victimization. Justice Q. 19(1):159-80

Shaffer JN, Ruback RB. 2002. Violent victimization as a risk factor for violent offending among juveniles. Rep., Off. Juv. Justice Delinquency Prev., Washington, DC. https://www.ojp.gov/pdffiles1/ojjop/195737.pdf 
Sheley JF, Wright JD. 1995. In the Line of Fire: Youths, Guns, and Violence in Urban America. Piscataway, NJ: Transaction Publ.

Singer SI. 1981. Homogeneous victim-offender populations: a review and some research implications. J. Crim. Law Criminol. 72:779-88

Singer SI. 1986. Victims of serious violence and their criminal behavior: subcultural theory and beyond. Violence Vict. 1(1):61-70

Skinner GC, Farrington DP, Shepherd JP. 2020. Offender trajectories, health and hospital admissions: relationships and risk factors in the longitudinal Cambridge Study in Delinquent Development. J. R. Soc. Med. 113(3):110-18

Slutkin G, Ransford C, Decker RB. 2015. Cure violence: treating violence as a contagious disease. In Envisioning Criminology: Researchers on Research as a Process of Discovery, ed. MD Maltz, SK Rice, pp. 43-56. Cham, Switz.: Springer

Sparks GH, Dodd D. 1977. Surveying Victims. London: Wiley

Sparks R. 1982. Research on Victims of Crime: Accomplishments, Issues, and New Directions. Washington, DC: US Gov. Print. Off.

Stewart EA, Schreck CJ, Simons RL. 2006. "I ain't gonna let no one disrespect me”: Does the code of the street reduce or increase violent victimization among African American adolescents? J. Res. Crime Delinquency 43(4):427-58

Sykes GM, Matza D. 1957. Techniques of neutralization: a theory of delinquency. Am. Sociol. Rev. 22(6):664-70

Taylor BG, Mumford EA, Liu W, Berg M, Bohri M. 2019. Young adult reports of the victim-offender overlap in intimate and nonintimate relationships: a nationally representative sample. Crim. Justice Behav. 46(3):415-36

Tedeschi JT, Felson RB. 1994. Violence, Aggression, and Coercive Actions. Washington. DC: Am. Psychol. Assoc.

Thornberry TP, Figlio RM. 1974. Victimization and criminal behavior in a birth cohort. In Images of Crime: Offenders and Victims, edited by TP Thornberry, E Sagarin, pp. 102-12. New York: Praeger Publ.

Tillyer MS, Wright EM. 2014. Intimate partner violence and the victim-offender overlap. J. Res. Crime Delinquency 51(1):29-55 
Tseloni A, Pease K. 2003. Repeat personal victimization: "boosts" or "flags"? Br. J. Criminol. 43(1):196-212

Turanovic JJ, Pratt TC. 2019. Thinking about Victimization: Context and Consequences. New York: Routledge

Van Gelder JL, Averdijk M, Eisner M, Ribaud D. 2015. Unpacking the victim-offender overlap: on role differentiation and socio-psychological characteristics. J. Quant. Criminol. 31(4):653-75

Wellford CF. 1997. Controlling crime and achieving justice: the American Society of Criminology 1996 presidential address. Criminology 35:1-12

Wikström P-OH, Oberwittler D, Treiber K, Hardie B. 2012a. Breaking Rules: The Social and Situational Dynamics of Young People's Urban Crime. Oxford, UK: Oxford Univ. Press

Wikström P-OH, Treiber K, Hardie B. 2012b. Examining the role of the environment in crime causation: small-area community surveys and space-time budgets. In The SAGE Handbook of Criminological Research Methods, ed. D Gadd, S Karstedt, SF Messner, pp. 111-27. London: Sage

Wilcox P, Tillyer MS, Fisher BS. 2009. Gendered opportunity? School-based adolescent victimization. J. Res. Crime Delinquency 46(2):245-69

Wolfgang M. 1958. Patterns in Criminal Homicide. London: Oxford

Wright RT, Decker SH. 1997, Armed Robbers in Action: Stickups and Street Culture. Boston: Northeastern Univ. Press

von Hentig H. 1948. The Criminal and His Victim: Studies in the Sociobiology of Crime. New Haven, CT: Yale University 